\title{
Marketing Of Craft To Retailers: Understanding Their Buying Process, Supplier Selection Criteria And Information Sources Used
}

KM Makhitha, University of South Africa, South Africa

\begin{abstract}
The purpose of the study was to investigate the buying process, supplier selection criteria and information of craft retailers in South Africa (SA). The information collected about the buying process, supplier selection criteria and information sources used were to propose a marketing strategy for craft producers wanting to target retailers. Craft retailers play a dominant role in the craft industry value chain yet craft producers face difficulties selling to this market. Instead, they resort to selling directly to end consumers and not through craft retailers. An understanding of the retailer's buying process, supplier selection criteria and information sources is a necessity for craft producers who want to sell their products successfully through the craft retailers. A survey was conducted among 233 craft retailers in SA. A convenience sampling method was adopted for the study. The findings revealed that craft retailers go through homogenous buying stages. Craft retailers go through a lengthy process when buying crafts. The most important supplier selection criteria are product quality, product is exciting and attractive, product styling and design and product distinctiveness/uniqueness. The information sources most often used are existing sales records, buyer's experience and sales persons visiting with samples.
\end{abstract}

Keywords: Buying Process; Craft; Craft Product; Craft Retailers; Craft Producers; Marketing Strategy; Supplier Selection Criteria; Information Sources

\section{INTRODUCTION AND BACKGROUND}

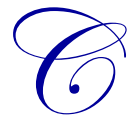

raft products are defined as those produced by artisans, either completely by hand, or with the help of hand tools or even mechanical means, as long as the direct manual contribution of the artisan remains the most substantial component of the finished product. These are produced using raw materials from sustainable resources. The special nature of artisanal products derives from their distinctive features, which can be utilitarian, aesthetic, creative, culturally attached, decorative, functional, religiously and socially symbolic and significant (UNESCO, 1997).

In South Africa (SA), a craft product is defined as "the creation and production of a broad range of utilitarian and decorative items produced on a small scale, with hand processes being the significant part of the value-added content. The production of goods uses a range of natural and synthetic materials" (Department of Arts, Culture, Science \& Technology, 1998). Craft products include a wide range of products such as home furnishings, jewellery, fashion and fashion accessories, novelties and gifts, including corporate gifts, garden and outdoor products, curios and collectibles, one-of-a-kind high-value individually made products, and indigenous artefacts, which are culturally derived products (Department of Labour, 2011; Department of Trade \& Industry (DTI), 2005:11). Rogerson (2010) posits that craft products must be 80 percent handmade from different materials, which may include clay, natural fibres, beads, recyclable materials and textiles. 
There is an increasing demand for craft products globally, especially for home accessories and décor, gifts and products for garden and outdoor living, which are used simultaneously for decorative and functional purposes (USAID, 2006). The rise in consumers' disposable incomes and the tendency to accessorise and re-style homes with unique articles are the major driving factors of the surge in demand for crafts and decorative products (Frost \& Sullivan, 2005). In SA, recent decades have seen the opening of many home-ware stores such as PepHome, @ Home, @ Home Living Space, Mr Price Home and Woolworths Artistic Collection department, which operates from inside the Woolworths branches. All these retailers sell handcrafted products, which create opportunities for craft producers targeting craft retailers. Craft producers therefore need an understanding of the buying process, supplier selection criteria and information sources used so as to formulate effective and appropriate marketing strategies targeted at craft retailers

Craft producers are driven by their desire to satisfy their artistic sensibilities, yet they find themselves in a situation where they have to balance their artistic vision and market demand. Some craft producers are more driven by the former, which implies that they fail to meet market demands since some of their artistic visions do not reflect what craft retailers and end consumers want (Obiri, 2002; Torres, 2002). As a result, some craft producers create products with no economic benefit derived from these products. For craft producers to derive an economic benefit, they need to gain an understanding of the markets (Hay, 2008).

\section{LITERATURE}

\section{Buying Process}

Various models depicting the buying process have been published. The first organisational buyer behaviour model is the Robinson, Faris and Wind (1967) model. The model is also known as the buy grid model. It consists of the two sub-models, the buy phase and the buy class models. The buy phase model shows the steps that organisations follow in the buying process. There are eight stages, including recognition of a problem, determination of the product type needed, description of the product type needed, search for and qualification of potential suppliers, requisition and analysis of proposal, evaluation of proposal and selection of suppliers, selection of order routine and performance review (Hutt \& Speh, 2007). The buy class model is not the focus of this resarch and will not be discussed here.

Other models of organisational buyer behaviour include those developed by Webster and Wind (1972), De Boer, Labro and Morlacchi (2001) and Luo, Wu, Rosenberg and Barnes (2009). The model of Webster and Wind (1972) depicts the stages in the buying process as well as the tasks a buyer performs and the factors influencing such tasks during the buying process. The De Boer et al. (2001) model reflects four steps in the buying decision: problem recognition, formulation of criteria, qualification of suppliers, and final selection of suppliers. This model emphasises the relative importance of supplier selection and evaluation during the buying process. The Luo et al. (2009) model shows four stages followed by a buyer during the process of suppler selection: the supplier selection preparation, pre-classification, final selection and application feedback.

The Sheth (1981) model is the only model depicting the buyer behaviour of retailers. This model was adapted from the Sheth (1973) model and was developed specifically for adoption by retailers. The model focuses on factors affecting retail buyers and the criteria retailers use during the buying process. The buying process investigated from this research was adapted from the above models and listed all the stages in the process as stated above.

\section{Supplier Selection Criteria}

Supplier selection criteria have been the subject of investigation for more than four decades (Da Silva, Davies \& Naude, 2002; Hansen, 2001; Kahraman, Cebeci \& Ulukan, 2003; Kim \& Boo, 2010; Lin \& Wu, 2011). These studies investigated and rated different supplier selection criteria across types of retailers, organisations, products and industries. Supplier selection criteria consist of a list of criteria or factors that retailers generate whenever supplier selection decisions have to be made, as well as when determining which supplier purchases will be made (Braglia \& Petroni, 2000). Supplier selection criteria must be tailored to meet the needs of specific retailers, 
who depend on the information available about the industry (Luo et al., 2009). Supplier selection criteria differ from one type of purchasing situation to another and from one organisation to another (Dempsey, 1978; Webster \& Wind, 1996; Sheth, 1981).

Lin and $\mathrm{Wu}$ (2011) listed 28 supplier selection criteria for supermarket chains in Taiwan. The ten most important criteria, in order of importance, were procurement price, product quality, product consistency, food safety, product return and complaints policy, quantity discount and allowance, on-time delivery, professionalism of salespeople and delivery reliability. In assessing the clothing retail buyer supplier selection criteria, Da Silva Davies and Naude (2002) identified, in order of importance, quality, delivery time and cost as the most important criteria. Hansen (2001) also studied supermarket supplier selection criteria and listed high product quality, the supplier's reliability, policy regarding return/handling complaints, high service level, willingness to cooperate, ability to supply products based on demand, products certified by authorised organisation, competitive prices, broad product range and flexibility of the supplier as the ten most important criteria for supplier selection. Kim and Boo (2010) also identified products that meet current trends as one of their ten most important supplier selection criteria.

USAID (2006) listed the six most important criteria for craft retailers when evaluating suppliers. These include quality, design, price, capacity, delivery and organisation skills. The quality criteria include the quality of the materials used in the production process, the craftsmanship (how the product is made) and the finish (type of polish or paint used, accuracy of colour and how finely edges are filed). Furthermore, the consistency (handcraft items must be consistent in design and dimensions, even though they are not identical) and the packing and shipping (whether it is well-packed, in clean materials that prevent damage and whether it is cost effective). An assessment of quality is also made by taking into consideration whether the product is handmade or mass produced. Some researchers argue that mass-produced products are not considered craft products (Luutonen, 2009).

It is evident from the findings above that that retailers have to formulate supplier selection criteria relevant to their organisations and markets since they differ across organisations and markets served. The fact that there are different criteria makes it even more difficult to draw conclusions regarding the criteria used by different retailers. The ability of craft retailers to identify suitable criteria for specific products and buying situations is clearly critical to the success of the product and the organisations.

\section{Information Sources}

To make effective and efficient buying decisions, buyers consult different sources of information available including external and internal sources of information. External sources include customers, salespeople/suppliers, advertisements, trade news, exhibitions, buyers from similar stores/comparison shoppers, customer requests, past sales, fashion forecasters, magazines read by customers, the Internet, reporting services and buying offices (Clodfelter, 2008). Written materials such as pamphlets, letters, advertisements, new items forms (forms drafted by the selling company and completed by the salesperson) are also useful sources of information (Sternquist \& Chen, 2006). Internal sources of information are information sources available within the organisation such as past sales and recording systems such as recording and computerisation (Diamond \& Pintel, 2008). It is important for suppliers to ensure that information about their products is available in the sources consulted by retailers, and this study aims to determine how often selected information sources are consulted.

Jackson, Keith and Burdick (1987) investigated the relative importance of various promotional elements in different purchase situations as perceived by industrial buyers. The study was unable to conclude that the relative importance of promotional elements varies with buy class. It found that the relative importance of promotional elements varies by product type. Salespeople were identified as the most important source of information used by industrial buyers, followed by trade advertising. Kline and Wagner (1994) also determined the relative importance of information sources used by retail buyers. They revealed that buyers used their own knowledge as their most important source of information, followed by customer requests, magazines read by customers, selling records and buyers from similar stores. Another study conducted by Brossard (1998) identified site visits as the most important source of information during a complex decision-making process, followed by in-house networks. 
Some retail buyers rely on their own personal experience instead of external commercial sources (DeeterSchmelz \& Kennedy, 2002), which is the case mainly with experienced buyers. Inexperienced buyers who have no prior knowledge and experience of buying a particular product rely on external sources. Buyers also consult their own experiences when they seek out sources of information (Kline \& Wagner, 1994).

It is important for the craft producers to understand the specific information craft retailers look for when sourcing information. For example, fashion retailers look for information on product quality, types of merchandise carried, product or merchandise styles, colour, fabrics and fibre, care, service and warranties and guarantees (Clodfelter, 2008). The utilisation of the Internet by craft producers is very low, and the opportunities associated with the Internet have not been exploited fully (Department of Sports, Arts, Culture and Recreation, 2007).

\section{MARKETING STRATEGY}

McCarthy \& Perreault (1999) define marketing strategy as a marketing activity that specifies a target market and its related marketing mix elements/activities such as product, promotion, price and place (distribution). It specify the target market for a particular product or product line and ensure that all marketing mix elements are integrated for competitive advantage and tailored to meet customer needs (Walker, Mullins \& Larréché, 2008). Marketing strategy determines how an enterprise is going to compete against its major rivals and involves determining the competitive advantages, which may arise as a result of the enterprise's ability to perform better than its competitors in some areas (Venter \& Janse Van Rensburg, 2009). This research will adopt McCarthy and Perrault (1999) definition of marketing strategy when proposing a marketing strategy targeted at craft retailers.

\section{PROBLEM STATEMENT AND OBJECTIVES}

The craft industry is dominated by small and medium craft producer organisations (Hay, 2008). It is crippled by the lack of reliable and accessible research data (Department of Economic Development, 2009), which impedes the industry's development and competitiveness. Marketing and branding are major challenges faced by the craft producers in South Africa (Department of Sports, Arts, Recreation \& Culture, 2007).

A study conducted among craft producers in Gauteng, South Africa revealed that they experience difficulties selling to craft retailers and that craft retailers purchase only 36 percent of craft products from SA (Department of Sports, Arts, Recreation and Culture, 2007). The Wesgro (2000) study also confirmed that craft producers have limited access to the craft retail market since they face competition from foreign craft producers who are far more advanced than the local ones (Department of Sports, Arts, Recreation \& Culture, 2007). As a result, some craft producers resort to selling directly to end consumers, using direct channels instead of selling through the retailers (Wesgro, 2000). Craft retailers are creators of the markets, developers of new products and are also able to source new products (Hay, 2008). They communicate with craft producers to ensure that quality control measures are taken and that innovation and product development is up to standard (Urban-Econ Tourism, 2010).

Craft producers face numerous marketing-related challenges in SA. They lack understanding of what the market needs, which leads to an inability to formulate appropriate and competitive product and marketing strategies (Grobler, 2005). Craft producers often sell similar products that do not address market demands and they have difficulty in accessing the markets (Department of Sports, Arts, Recreation \& Culture, 2007:10; Hay, 2008:13; Makhitha \& Bresler, 2011). Craft producers also lack skills in product design, distribution and organisation management (DTI, 2005) and possess limited knowledge of the lifestyles and product preferences of their potential customers and the promotional strategies needed to target them (Littrell \& Miller, 2001). As stated in Urban-Econ Tourism (2010), craft producers copy each other's product designs and these results in products, which lack innovativeness and uniqueness. Because they are not informed about the market and are unable to produce the quality and quantity it demands, they cannot access the retail market. Therefore, the purpose of the study was to investigate the buying process, supplier selection criteria and information sources retailers' use when buying crafts. The information will be used to propose a marketing strategy for craft producers selling to retailers. The objectives of the study are as follows: 
- $\quad$ To determine the buying process retailers go through when buying craft products.

- $\quad$ To identify supplier selection criteria retailers use when evaluating craft producers as their suppliers.

- To determine information sources retailers use when searching for craft producers as their suppliers.

\section{METHODOLOGY}

The study adopted a survey method targeted at craft retailers in South Africa. This included craft retailers of different types and sizes such as craft shops, small interior and gift stores, interior and decor shops, discounts retailers, clothing shops, furniture shops, museums, galleries, jewellery shops and destination retailers. A nonprobability convenience sampling method was adopted owing to the difficulties of identifying craft retailers and the fact that there was no reliable and easily accessible database of craft retailers. According to Cooper and Schindler (2006) convenience sampling is suitable when there are time constraints and lists of available units are either incomplete or not up-to-date, as with the case of SA craft retailers.

Data were collected electronically through email as well as personally hand delivered questionnaires to craft retailers for self-completion. The total number of questionnaires sent out to craft retailers was 681 , however, only 233 were considered usable. The other questionnaires were incomplete. The questionnaire was of a selfcompletion nature and was designed using information collected from a preliminary qualitative study (interviews) which was conducted among craft retailers and industry experts as well as from the literature. Respondents were requested to indicate which stages in the buying process they go through by answering either Yes or No. The supplier selection criteria were measured on a scale of one to five, with $1=$ strongly disagree and $5=$ strongly agree. Respondents were also requested to indicate how frequently they utilised the various information sources identified on a four-point Likert scale ranging from (1) never to (4) always. The buying stages, supplier selection criteria and information sources were all identified from the literature and the preliminary qualitative research conducted. There were 16 stages in the buying process listed in the questionnaire. Of the 16 stages, five were identified from the preliminary research. Whilst 33 supplier selection criteria were listed on the questionnaire, 11 were identified from the preliminary qualitative research. With the information sources, 20 sources were listed on the questionnaire. Five of the sources such as visits to craft wholesalers, news stories in trade publications, trade association information, and suppliers' catalogues were identified from the preliminary study. Due to the low response rate, data were collected from formal craft retailers operating in six provinces, including Gauteng, Western Cape, Kwazulu-Natal, Mpumalanga, North West and Eastern Cape.

The Cronbach's alpha for the supplier selection criteria scale was 0.90 and for the information sources scale 0.83 , indicating satisfactory internal consistency reliability for both these measures. Malhotra (2010:319) deemed a Cronbach alpha of 0.70 to be an indication of satisfactory internal consistency reliability. The questionnaire was pretested using the participant pre-test method with $12 \mathrm{craft}$ retailers and the wording of some questions were altered slightly to ensure clarity. Furthermore, craft retailers did not receive any incentives and participation was voluntarily.

Data were analysed using SAS software. Descriptive statistics, factor analysis and ANOVA tests were conducted and the results are reported and discussed in the next section.

\section{ANALYSIS AND INTERPRETATION OF FINDINGS}

\section{Descriptive Statistics}

The sample consisted of various types of retailers. Of the 233 respondents, 94 were craft stores, representing 44 percent of the total population. Destination retailers were the next biggest group, representing about 16 percent $(n=35)$ of the population, followed by the small interior/gift stores with about 12 percent $(n=27)$ of the population. The rest of the respondents comprised of clothing stores, discount stores, furniture stores, galleries, museums, jewellery shops, and destination retailers, but these had a very small representation. For the purpose of statistical analysis, craft retailers were collapsed into five groups: the craft stores, small interior/gift stores, large retailers such as interior décor/homeware stores, clothing stores, discount stores and furniture stores, speciality stores such as galleries, museums and jewellery shops, and destination retailers. The five groups excluded the 'other' 
category since there were no types of retailers mentioned. Therefore, the five groups consisted of 214 responses. The representation of the five groups were as follows: craft stores (44\%), small interior/gift stores (13\%), large retailers such as clothing and décor stores (14\%), speciality stores such as galleries, museums and jewellery shops (13\%) and destination retailers $(16 \%)$.

The respondents consisted of buyers, managers, owner-managers, manager-buyers and executives responsible for buying. The owner-managers were the largest group, comprising 44 percent $(n=101)$ of the population. Managers were the second largest group of respondents, comprising over 18 percent $(n=42)$ of the population. This was followed by manager-buyers, with about 14 percent of the population $(n=31)$. Buyers made up over 12 percent of the population $(\mathrm{n}=28)$. The last group of respondents were the executives, who represented about 12 percent of the population, consisting of 27 respondents.

\section{Buying Process}

Table 1 depicts the stages in the buying process according to the order of use. The stage, which craft retailers use most when buying crafts is 'we identify a need for craft products', as indicated by almost 94 percent of respondents. This stage was followed by 'we determine the characteristics and/or quantity of the craft products needed', as shown by over 91 percent of the sample, 'we evaluate and/or select craft suppliers', with just over 87 percent of the population, 'we negotiate trading terms of suppliers', represented by over 87 percent of the sample and 'we search for potential suppliers', represented also by over 87 percent of the sample. The least used stage in the buying process of a craft retailer is 'we develop a contractual agreement with the supplier', agreed to by about 66 percent of the sample, followed by 'we create a precise description of the craft products needed', which was agreed to by about 67 percent of the sample. The third least-used stage in the buying process of the craft retailers was found to be 'we place trial order/s and finalise the approval of suppliers', as indicated by over 72 percent of the sample.

- Another important aspect worth noting in the buying process is the fact that 28 percent $(\mathrm{N}=64)$ of craft retailers revealed that they did not place trial orders to finalise the approval of suppliers.

- Some craft retailers, as indicated by 34 percent of the respondents, did not enter into contractual agreements.

- It is evident that the majority of craft retailers go through a lengthy buying process.

Table 1. Stages in the buying process

\begin{tabular}{|c|c|c|c|c|c|}
\hline \multirow{2}{*}{ Buying stages } & \multirow{2}{*}{$\mathbf{N}$} & \multicolumn{2}{|c|}{ Frequencies } & \multicolumn{2}{|c|}{ Percentages } \\
\hline & & Yes & No & Yes & No \\
\hline We identify a need for craft products & 231 & 219 & 14 & 93.99 & 6.01 \\
\hline $\begin{array}{l}\text { We determine the characteristics and/or quantity of the craft products } \\
\text { needed }\end{array}$ & 232 & 210 & 22 & 90.52 & 9.48 \\
\hline We evaluate and/or select craft suppliers & 233 & 203 & 30 & 87.12 & 12.88 \\
\hline We negotiate trading terms with suppliers & 231 & 202 & 30 & 87.07 & 12.93 \\
\hline We search for potential suppliers & 232 & 202 & 30 & 87.07 & 12.93 \\
\hline We expedite and evaluate the supplier's and product performance & 231 & 200 & 31 & 86.58 & 13.42 \\
\hline We estimate the demand for a particular craft item & 231 & 195 & 36 & 84.42 & 15.58 \\
\hline We decide how much stock to keep and therefore how much to invest & 233 & 194 & 39 & 83.26 & 16.74 \\
\hline $\begin{array}{l}\text { We determine the product assortment, i.e. product lines/range and number of } \\
\text { product per product line) }\end{array}$ & 230 & 188 & 42 & 81.74 & 18.26 \\
\hline We visit and/or interact with the supplier to learn more about them & 232 & 187 & 45 & 60.60 & 19.40 \\
\hline We provide the suppliers with feedback about their product performance & 232 & 184 & 48 & 79.31 & 20.69 \\
\hline We place replenishment orders, i.e. more quantities after the first trial order & 232 & 176 & 56 & 75.86 & 24.14 \\
\hline We formulate the criteria that will be used to evaluate suppliers & 232 & 170 & 62 & 73.28 & 26.72 \\
\hline We place trial order/s and finalise the approval of suppliers & 232 & 168 & 64 & 72.41 & 27.59 \\
\hline We create a precise description of the craft products needed & 231 & 154 & 77 & 66.67 & 33.33 \\
\hline We develop a contractual agreement with the supplier & 231 & 152 & 79 & 65.80 & 33.77 \\
\hline
\end{tabular}




\section{Supplier Selection Criteria}

Table 2 below presents the supplier selection criteria in terms of the importance attached to each criterion by retailers. The following can be deduced from the table:

- The five most important supplier selection criteria, based on mean value and in order of importance, were: product quality, product is exciting, product styling and design, product distinctiveness/uniqueness, supplier's willingness to cooperate with us.

- The five supplier selection criteria rated least important were products are branded, products are certified by authorised organisations such as SABS or Proudly SA, supplier provides product training, financial position of a supplier and supplier provides marketing support.

- $\quad$ Products are branded was least important to craft retailers, followed by products are certified by authorised organisations such as SABS or Proudly SA, supplier provides training, financial position of a supplier and supplier provides marketing support.

Table 2. Supplier selection criteria

\begin{tabular}{|c|c|c|c|}
\hline $\begin{array}{c}\text { Order of } \\
\text { importance }\end{array}$ & Supplier selection criteria & $\mathbf{M}$ & SD \\
\hline 1 & Product quality & 4.59 & 0.71 \\
\hline 2 & Product is exciting and attractive & 4.39 & 0.74 \\
\hline 3 & Product styling and design & 4.18 & 0.87 \\
\hline 4 & Product distinctiveness/unique & 4.18 & 0.90 \\
\hline 5 & Supplier's willingness to cooperate with us & 4.18 & 0.97 \\
\hline 6 & Product's sales potential, i.e. product will sell & 4.17 & 0.93 \\
\hline 7 & The ability to supply products based on our demand/requirements & 4.15 & 0.92 \\
\hline 8 & Supplier capacity, i.e. the ability to supply needed quantity & 4.13 & 0.99 \\
\hline 9 & Delivery reliability, i.e. the ability to deliver on time & 4.12 & 1.17 \\
\hline 10 & Total cost of acquiring the product & 4.08 & 0.99 \\
\hline 11 & Supplier's willingness to negotiate prices & 4.07 & 1.04 \\
\hline 12 & Supplier introduces new products or improvements from time to time & 3.91 & 1.07 \\
\hline 13 & Good product ideas that match current trends & 3.88 & 1.07 \\
\hline 14 & Ability of the product to fit in with existing ranges & 3.88 & 1.08 \\
\hline 15 & Products are handmade & 3.87 & 1.20 \\
\hline 16 & The convenience of placing orders with the supplier & 3.86 & 1.05 \\
\hline 17 & The flexibility of the supplier to accommodate our changing needs & 3.84 & 1.05 \\
\hline 18 & Established long-term relationship with the supplier & 3.80 & 1.22 \\
\hline 19 & Supplier provides new and interesting product idea/s & 3.75 & 1.01 \\
\hline 20 & Reputation of a supplier & 3.74 & 1.25 \\
\hline 21 & The supplier has quality management systems in place & 3.73 & 1.22 \\
\hline 22 & Upliftment/empowerment of small organisations & 3.72 & 1.19 \\
\hline 23 & Supplier offers competitive prices & 3.72 & 1.24 \\
\hline 24 & Product is fashionable & 3.72 & 1.36 \\
\hline 25 & Supplier offers a broad range of products & 3.58 & 1.26 \\
\hline 26 & Origin of the product & 3.55 & 1.31 \\
\hline 27 & Our history with the supplier & 3.43 & 1.30 \\
\hline 28 & Supplier accepts product returns if there is product failure & 3.43 & 1.44 \\
\hline 29 & Locally manufactured crafts & 3.33 & 1.34 \\
\hline 30 & Products are packaged according to our requirements & 3.33 & 1.37 \\
\hline 31 & The supplier provides us with product and organisation information & 3.32 & 1.35 \\
\hline 32 & Supplier provides after-sales service/support & 3.14 & 1.48 \\
\hline 33 & Suggested retail price & 3.03 & 1.44 \\
\hline 34 & Products have a swing tag with information & 2.81 & 1.43 \\
\hline 35 & Supplier provides marketing support & 2.72 & 1.35 \\
\hline 36 & Financial position of the supplier & 2.57 & 1.48 \\
\hline 37 & Supplier provides product training & 2.53 & 1.42 \\
\hline 38 & Products are certified by authorised organisations, i.e. SABS, proudly SA & 2.51 & 1.55 \\
\hline 39 & Products are branded & 2.36 & 1.43 \\
\hline
\end{tabular}




\section{Information Sources}

The descriptive results indicated that some of the sources of information were used more often than others. Therefore, the sources of information were listed according to the order of use, as shown in Table 3.

Table 3. Information sources most often used by craft retailers

\begin{tabular}{|c|c|c|c|}
\hline $\begin{array}{c}\text { Order of } \\
\text { Importance }\end{array}$ & Sources of information & M & SD \\
\hline 1 & Existing sales records & 3.08 & 0.97 \\
\hline 2 & Buyer's experience i.e. gained from buying craft products & 3.07 & 0.82 \\
\hline 3 & Craft producer visits us with product samples & 2.80 & 0.93 \\
\hline 4 & Ask existing suppliers to find us what we need & 2.77 & 1.04 \\
\hline 5 & Salespeople from the craft producer provides information & 2.65 & 0.98 \\
\hline 6 & Visit to craft wholesalers & 2.59 & 0.96 \\
\hline 7 & Information about suppliers from colleagues & 2.59 & 0.98 \\
\hline 8 & Visit to the craft producer workshop/studio & 2.57 & 1.11 \\
\hline 9 & Search the internet & 2.56 & 0.98 \\
\hline 10 & Supplier catalogues & 2.52 & 1.07 \\
\hline 11 & Visit to the trade show/exhibition & 2.50 & 0.94 \\
\hline 12 & Visit to competitor organisation/s & 2.47 & 1.02 \\
\hline 13 & Users/end consumers of craft product, i.e. through suggestions and queries & 2.45 & 0.94 \\
\hline 14 & Networking with buyers from similar craft stores & 2.41 & 1.01 \\
\hline 15 & Sales promotion materials from suppliers i.e. brochures and pamphlets & 2.27 & 0.99 \\
\hline 16 & Trade/industry association information/data & 2.14 & 0.99 \\
\hline 17 & News stories in trade publications & 2.09 & 0.86 \\
\hline 18 & Advertisement in trade news & 2.09 & 1.01 \\
\hline 19 & Advertisement in consumer magazines & 2.06 & 0.97 \\
\hline 20 & Research done by marketing research agencies on our behalf & 1.88 & 1.06 \\
\hline
\end{tabular}

From Table 3, it is evident that:

- $\quad$ The five most often used sources of information were: sales records, buyer's experience, craft producer visits us with product samples, ask existing suppliers to find us what we need and salespeople from the craft producers provide us with information.

- $\quad$ Existing sales records and buying experience were sources used most often. This implies that craft retailers make more use of internal sources of information than external sources such as research organisations, advertisements and trade shows/exhibitions.

- $\quad$ The five least-often used sources of information were found to be 'research done by marketing research agencies on our behalf' $(M=1.88)$, 'advertising in consumer magazine', 'advertising in trade news 'news/stories in trade publications' and 'association/industry trade information data' which have the lowest mean scores.

- It appears that craft retailers do not often use sources of information such as advertisements that are available through mass media.

- With regard to marketing research, the majority of craft retailers are small organisations that, for economic reasons, could possibly not afford the use of market research agencies.

\section{RECOMMENDATIONS}

Craft producers need to research the different kinds of products their targeted retailers carry and develop, and hence design products that match the needs of these retailers. This includes the collection of information by talking to craft retailers to determine whether products have been satisfactory. Such information can be used to improve the craft producer's marketing strategy. Craft producers can also use the information when negotiating with craft retailers on areas that were found to be unsatisfactory.

It is essential for craft producers to be aware of market trends and competitors' products and prices. They should access information useful to them by remaining informed of current trends, issues and constraints in the 
market. They also need to understand the total costs of ownership incurred by craft retailers, an aspect that will be important when setting and negotiating prices. The researching of new product ideas and the continuous development of products that will sell is essential.

Craft producers should match current trends in terms of product quality, styling and design, uniqueness and products that are exciting and attractive, since these product attributes could change over time. Since good ideas might become dated, continuous research into new ideas could make craft producers successful. For craft producers to supply the right product at the right time and in the right quantity, they would need to estimate what craft retailers will demand and start to prepare production ahead of time.

There are many Internet websites providing ideas on new trends, product styles and designs, which can be accessed by craft producers. However, this requires that craft producers have access to the Internet. There are also many interior décor magazines, some of which publish product designs, which could be used as a source of new ideas. Craft producers can use magazines dealing with topics such as interior design, houses and gardens, fashion footwear, art and general household matters to learn about fashion trends, which could be incorporated into their product designs and styles. Such publications allow them to keep up with current trends as well as popular colours, product sizes and designs. Visiting competitors can window-shop and observe what is for sale and what is purchased frequently, which is a valuable means of studying changing trends.

\section{Target Marketing and Positioning}

Since there are various types of craft retailers in SA, it could be necessary for craft producers to target certain retailers whose needs they are able to meet. The study investigated five types of craft retailers consisting of craft stores, small interior and gift stores, large retailers, speciality retailers and the destination retailers. Emphasis should be placed on quality, the product is exciting, product styling and design, product distinctiveness/uniqueness, supplier's willingness to cooperate with retailers, product's sales potential, the ability to supply products based on retailers' demand/requirements, supplier capacity, delivery reliability and total costs of acquiring the product. Craft producers must also position their organisations and products against their competitors by using any of the 10 most important supplier selection criteria and position their organisations and products against these criteria. Continuous effort should be made to improve the craft producers' position against the most important criteria.

\section{Craft Product Strategy}

There is a need for craft producers to understand the needs of craft retailers so that they do not waste scarce resources on developing products that are not needed by craft retailers. The majority of craft retailers go through an extended buying process involving 16 stages. Craft producers must get involved in each of the stages in order to influence craft retailers' buyer behaviour. For example, the two most used stages are 'we recognise the need for craft products' and 'we determine the characteristics and quantity of products to be bought'. Craft producers could take their new product ideas to craft retailers and discuss the ideas with them, thus enabling them to see if craft retailers like the idea and whether they will want to buy the product. This is possible only if craft producers have researched new product ideas that match the current trends.

If craft producers become involved in the stage when craft retailers determine the characteristics and the quantity of products needed, they will be able to define product characteristics, which they must incorporate into their new products during the new product design and development stages. The involvement of the craft producer in the planning of quantities to be ordered will enable craft retailers to be aware of the available supply. However, this requires that craft producers develop close working relationships with craft retailers.

It is of the utmost importance that craft producers understand the specific product requirements of craft retailers so that they can develop products to meet those requirements. Since the majority of craft retailers (73 percent) formulate the supplier selection criteria for evaluating craft producers during the buying process, craft producers need to identify these criteria so that they can work on incorporating them in their marketing and business strategy. This can be achieved in different ways such as by visiting craft retailers, bringing new product ideas or samples to discuss with them or by asking retailers what they look for in specific products. Although this study has 
identified the most important supplier selection criteria, these change over time and craft producers must keep abreast of these changes. For those retailers that do not have a precise description of products during the buying process, craft producers would have to ensure that they develop products that match the most important supplier selection criteria so as to create an awareness of their products with craft retailers.

What is important to craft retailers is product quality first, followed by products that are exciting and attractive, the styling and design of the product, product distinctiveness/uniqueness and the product's sales potential. Craft producers must focus on these criteria during the new product design and development stages, ensuring that products created are of a high quality, attractive and unique, thereby increasing the sales potential of the product.

Products of high and consistent quality need to be developed by craft producers to satisfy the needs of craft retailers. Craft producers might upgrade and maintain product quality by ensuring that the right kind of raw material, suitable for a higher quality end product, is used. They could also ensure regular control during the production process, allowing them to deliver a more consistent product quality. In addition, craft producers could apply strict final quality control measures before sending the products to retailers. They might also need to emphasise quality throughout their transactions with retailers, who are often on the lookout for new suppliers and something new and different.

Developing similar products but with different designs and styles might allow craft producers to target different craft retailers who have different product requirements. This will also enable craft producers to provide a broader range of products from which craft retailers can select what is best suited to their stores. Retailers might also want to carry more than one kind of product design. For example, while the Kim Sacks gallery sells various craft products, the gallery also has a large section displaying ceramics products of different kinds, which are highly exclusive and highly priced. There will be a need to balance the quality of products with the prices set. Retailers such as Makro and Pick n Pay Hyper, which are large stores, would sell ceramics that are unique and of high quality but moderately priced since the majority of their target market belongs to the middle class.

It is essential that craft producers develop and update their products from time to time and keep track of changing trends. In addition to updating product quality, craft producers must also update product designs and styles to make products look unique. It is important that craft producers avoid copying other producers' ideas since this limits their ability to offer styles that are unique and can be identified with their organisation. Product development must be a continuous exercise that ensures that creativity and innovation are the first priority. Because of the diversity of craft products, craft producers should note trends affecting the different types of products they produce. For example, retail markets such as the décor markets are fashion driven and their needs change continuously.

Moreover, craft producers can also take advantage of the fact that the majority of craft retailers go through a trial stage by using this stage to test their quality levels and ability to deliver sufficient quantities on time. During this stage, information on product performance can be collected and product requirements negotiated with the retailers to ensure that the product meets their needs.

Craft producers could ensure that product designs remain relevant to the traditional, transitional and modern styles as required by craft retailers. The traditional designs are driven by age-old designs as well as by culture and traditions. Modern designs keep up with changes in the preferences and taste of craft buyers while the transitional is a combination of traditional and modern.

There are different types of craft retailers who sell different products within their retail stores. For example, speciality craft retailers specialise in craft products and buy any kind of craft, while destination retailers focus more on travel, thus emphasising gifts and souvenirs. Craft producers might need to develop different product types for different craft retailers to ensure that they have enough product lines to sell to a variety of craft retailers as well as to satisfy the needs of retailers that want variety within their stores. However, the number of product lines will be dependent on the availability of resources. The formation of cooperatives could enable craft producers to add more product lines than a one-man organisation can do. 
Branding, although only slightly important to craft retailers, can also be used. The name of the artist (craft producer) may be used as a brand name. This is important for managing the reputation of the organisation since the reputation gained by the artist could be transferred to the products the artist produces. When marketing to international markets, it is useful for craft producers to use the name of the place or country where the product was made. This combines branding with another, more important, criterion - place of origin - an important one for craft stores. Some craft producers, such as Carrol Boyes, have successfully used branding to make their products unique and are commanding high prices for their branded products. Branding, product identity and originality are very important in order to distinguish products from the mass-produced equivalent.

The use of suitable packaging and appropriate packing materials for certain products, with the name of the company and contact details of the producer on the packaging, can also reflect the branding to create a quality image and identify the source of origin. Attaching a swing tag serves a number of purposes: contact details can be included so that customers can access the craft producers and be given more information about them. Tourists want information on how the product is made and the types of materials used. This information written on a swing tag can be used for marketing purposes, especially for retailers such as destination stores, speciality stores and gift stores targeting tourists. Other items of information that can be included on the swing tag are that the product is locally manufactured or that the craft producers adhere to fair trade principles such as paying a fair wage in the local context, offering employees opportunities for advancement, providing equal employment opportunities for all people, particularly the most disadvantaged, and engaging in environmentally sustainable practices. Some regions are so well marketed and well known that craft producers can use the origin of the product as a marketing tool. For example, the CCDI has established the Handmade Cape brand, which communicates the origin of the product and can only be used by those craft producers in the Western Cape. Some large stores such as Makro, Pick n Pay Hyper and Checkers Hyper sell handmade items, which constitute only a small part of their product ranges. Craft producers should bear this in mind when selling to these retailers, as they need to ensure that they have the necessary production capacity.

\section{CRAFT PRODUCER MARKETING COMMUNICATION STRATEGY}

Marketing communication is another element of marketing strategy. Craft retailers search for suppliers during the buying process. To achieve the goal of identifying potential customers, craft retailers use various sources of information to learn about suppliers and their products. Craft producers could formulate an integrated marketing communication strategy using various sources to convey information to retailers. It is possible for craft producers to combine sources such as visits to craft retailers with samples, use of salespeople where possible to visit craft retailers, and promoting their products through wholesalers. Supplying information to the buyer's colleagues in a craft retailer organisation, encouraging craft retailers to visit their studios by sending out invitations or hosting open days are other possible methods. Craft producers might not be able to convey information using sales records and buying experience but can make sure that their products meet the most important supplier selection criteria for their products to sell and to create a positive, lasting buying experience for craft retailers, thus building good relationships and establishing a good track record.

Craft producers provide information that includes price changes, product shortages and date of availability, new products, discontinued items, changes in packaging, labelling, size and promotional activities. They should also ensure that product samples and price lists are readily available at all times upon the buyer's request. Additional information on financial stability, consistency of supply and ability to meet specific and varied delivery requirements may also be provided. Product lists and illustrations are useful to the retailer. When selling new products to retailers, craft producers are expected to supply information on the product and its composition, where ingredients are sourced, development history, other stockists and the retail price asked by competitors, which should be readily available.

One method of marketing products successfully to craft retailers involves visiting craft retailers with product samples. This enables craft retailers to see the products and they might then also negotiate product designs and styles with the craft producers. This is also an opportunity for craft producers to collect information, which might be useful in improving their products and to use the visit to discuss other product ideas with craft retailers. 
Another opportunity for craft producers lies in promotional information such as Internet use, catalogues and use of trade exhibitions. The Internet, while only moderately used by craft retailers, can also be used as a good method of conveying information to craft retailers. Craft producers must improve their use of the Internet to increase the image of their organisation and products, and also encourage retailers to adopt the use of the Internet. There are many websites such as Buy Africa, Arts Link and SA Arts that craft producers are able to use to market their products. SA Handmade and CCDI also publicise craft producers on their websites, which is something craft producers can take advantage of. Craft producers can use the Internet for developing their own websites, which can be expensive, or by using craft-related public websites such as those mentioned above.

Although retailers do not always make use of exhibitions to source producers, craft producers could still make use of these events to increase their business exposure by targeting exhibitions such as the SARCDA, which are aimed at specific craft retailers, to increase awareness of their organisations. Other exhibitions could also be targeted, depending on the target market of the exhibitions. For example, Decorex targets both end consumers and craft retailers, making it of value to craft producers. Exhibitions also provide an opportunity for craft producers to network with other producers and to identify the latest trends.

Catalogues showing different product designs and styles can be distributed to retailers, allowing them to select what they want. Forming a collective would allow craft producers to gain an economy of scale and share costs, enabling them to produce catalogues to be sent to retail stores for browsing. The CCDI also have product catalogues on their websites, which craft producers in the region may use. Craft producers, as a cooperative, can also approach government or its agencies for funding required for developing crafts catalogues. Product catalogues can also be distributed at exhibitions targeted at craft retailers. Craft producers need to consider working closely with associations, government agencies and departments, such as SA Handmade and the DTI, which offer support services to craft producers in the form of producing craft catalogues.

Craft producers, who will be able to control how the product is made and tell the story of their products, can also adopt the use of promotional videos or CDs. This is useful for retailers who would then be able to assess the products at their own convenience and might make suggestions as to the specifications of the product they order. Craft producers can distribute copies of videos or pictures of products to craft retailers via email, which is less costly and less time consuming.

\section{CRAFT PRODUCER PRICING STRATEGY}

Craft producers need to consider not only their own profit but also the profit margin of retailers. Craft retailers attach more importance to the total cost of ownership than to the competitive and suggested retail prices. This requires craft producers to understand the total costs of ownership since the price that craft retailers set is determined not only by the actual price they pay for the product but by all costs involved in acquiring the products, such as searching for suppliers, visiting suppliers, and transportation and promotion of products. Craft producers thus need an understanding of the costs involved in acquiring their products and to manage and control their costs accordingly, which will also enable them to price their products competitively. They should carefully determine their pricing strategy to ensure that it increases the sales potential of their products, which is an important criterion for craft retailers.

The majority of craft retailers operate from major shopping centres that charge high rental rates, which influence the prices craft retailers are willing to pay for craft products. The fact that craft retailers visit remote areas involves costs such as transportation, visits to craft producers, accommodation and delivery. Retailers also cover the costs of running a store and managing orders from under-resourced and widely dispersed suppliers, as well as for transporting products from craft producers to the retailers at times. The craft producers' selling price should be determined and included in order to set competitive prices. To do this, craft producers could analyse competitor prices and also determine if there are any standard prices for their products.

Therefore, instead of pricing for profit only, producers must look into competitor prices, their profit margin, the retailer margin as well as the retailers' costs of acquiring the product. Encouraging bulk buying could help craft producers cover costs through producing more of the same products, especially when selling to large retailers. When 
setting their prices, craft producers must also consider the quality of their products, their uniqueness as compared with products of other craft producers, the time spent in producing them and the quality of the raw materials. Prices should be compared with those of other craft producers. Information about the prices set by other craft producers can be collected by checking prices of competitors at retail shops or by visiting competitors' workshops to check and evaluate their prices. Craft producers could still ensure that they produce unique products by improving their product designs as and when needed and also by avoiding copying other producers' designs.

Craft producers must be able to negotiate prices with craft retailers and should learn the factors of negotiation such as responsiveness, price, time of payment, stock-keeping, cooperative activities, volume, delivery, product assortment, product quality and specifications. Moreover, craft producers should consider offering or negotiating discounts based on quantities bought. Where possible, discounts can also be offered for prompt payment. However, craft producers must ensure that their pricing strategy earns them profitability.

\section{Craft Producer Distribution Strategy}

Craft producers should re-evaluate their strategy regarding distribution of their products. They need to assess their willingness to cooperate with craft retailers, their ability to supply products based on craft retailer demand/requirements, their ability to supply sufficient quantity (capacity) as needed by craft retailers and their delivery reliability. These are the most important distribution-related supplier selection criteria that craft retailers look at when evaluating suppliers. Some of the reasons why craft producers cannot deliver reliably and on time are that they have no transportation and also lack resources to make sufficient products on time. They could encourage retailers to collect the stock after purchase or to hire third party transportation services. However, the latter could be more expensive than if retailers collected their stock. Where possible, craft producers can use public transportation to deliver the stock personally to retailers. Alternatively, craft producers can also use special parcel services for delivery of products.

To succeed in selling to craft retailers, craft producers could improve their supply capacity by targeting craft retailers whose quantity needs they can satisfactorily match. For example, they could first target small interior/gift stores that buy in small quantities and the larger retailers only when they are able to manufacture large quantities. They could also form cooperatives with other craft producers, which will enable them to supply enough to craft retailers. They could also consolidate orders, enabling them to increase their ability to deliver the right quantity on time while also meeting production, labelling and packing specifications.

Craft producers might try locating their workshops closer to their target market to ensure they are able to deliver on time and to reduce transportation costs. Craft producers in SA have a reputation of being unreliable, so must avoid delivering products late, delivering the wrong product/colour or never delivering at all. When such problems occur, they need to communicate with craft retailers and take corrective action such as referring the order to other craft producers who can supply the ordered products. It is necessary to check the order specifications against the delivery to ensure that the right products are delivered, as well as follow up with craft retailers after delivery to ensure that they have received the correct order.

It might also be important for craft producers to negotiate with craft retailers on how to meet their supply requirements. For example, supplying the needed products can be done over a period of time instead of at once. Craft producers should be able to produce the products as per ordered design and agreed price, ensuring that products are of consistent quality and following the instructions for labelling and packaging. Anticipating what craft retailers might need and when will also help craft producers to produce enough and be able to supply as and when needed. This would mean preparing to supply the quantities needed as well as development of products according to the specification of craft retailers. This stage applies only to those craft retailers that place the trial order first. Craft retailers could collect information about whether the craft retailer was satisfied or dissatisfied with the trial order and use the information to improve their marketing strategy.

Since some craft retailers enter into contractual agreements with craft producers, craft producers might emphasise this stage during the negotiation process to ensure they have repeat orders. This can also be used as a basis for building relationships with craft retailers and to discourage them from searching for new suppliers every 
time there is a need for new products. Where possible, craft producers could negotiate with those craft retailers that do not enter into contracts and persuade them to enter into a service level agreement with them.

Some craft retailers also place trial orders during the buying process. It is possible for craft producers to use this stage as an opportunity to prove their worth and their ability to deliver the products as ordered at the right time and in the right quantity. It is also at this stage that craft producers can negotiate trading terms with retailers.

Craft producers must ensure that craft retailers can place orders conveniently by making use of various methods such as visiting craft retailers to take orders, the use of emails or taking telephonic orders. This would offer craft retailers more options and increase the convenience of placing orders. However, the majority of craft producers rely on cell phones, where numbers can change over time. This means that craft producers are inaccessible by craft retailers. While email is convenient, some craft producers access the Internet only via an Internet café, which means they might not receive orders on time. Craft producers could balance the use of cell phones and email, but must make sure that they can always be reached by cell phone. Emails can be received on some cell phone handsets, which is an even more effective method of receiving orders for craft producers. The proposed craft sourcing enterprise can also be used by craft producers as a channel to close the gap between them and craft retailers by taking orders from retailers on behalf of craft producers.

Craft producers could provide marketing support if needed, and if they have the resources. For example, the Crafters Market, a craft retailer in SA, allows craft producers to merchandise their products and The Tiger's Eye expects craft producers to demonstrate how they make their products at some of their stores located at the airport, thus targeting international tourists who are interested in how products are made. However, this is not a very important criterion for retailers, and should not pose a big problem for small craft producers that do not have the capacity to provide such support.

Although some craft retailers do not develop contractual agreements with craft producers, craft producers could use those that do as testimonials to persuade potential retail customers to enter into contracts with them.

Because craft producers are small organisations, some of them cannot afford their own transport. Possibilities include making use of third party transport services or selling products excluding transportation costs so that craft retailers bear the cost of transportation. It is not advisable for craft producers to produce more stock for keeping in the storerooms/warehouses unless the products are highly in demand. However, where craft producers can identify needs and anticipate the demand for certain products, styles and designs, they could produce more stock to store in warehouses so that they will have enough to supply craft retailers.

If there is a lack of resources and craft producers find it difficult to supply the required stock in the right quantity, it may be possible for them to produce items during the low season and sell them during the high season. This requires that they study the market demands so that products will remain relevant in the high season.

\section{REFERENCES}

Braglia, M. \& Petroni, A. 2000. A quality assurance oriented methodology for handling trade-offs in supplier selection. International Journal of Physical Distribution \& Logistics Management, 30(2):96-111.

Brossard, H.L. 1998. Information sources used by an organization during a complex decision process: an exploratory study. Industrial Marketing Management, 27:41-50.

Cooper, D.R. \& Schindler, P.S. 2006. Business research methods. 9th ed. Boston: McGraw-Hill.

Clodfelter, R. 2008. Retail buying: from basics to fashion. 3rd ed. New York: Fairchild Books.

Da Silva, R., Davies, G. \& Naude, P. 2002. Assessing the influence of retail buyer variables on the buying decisionmaking process. European Journal of Marketing, 36(11/12):1327-1343.

Deeter-Schmelz, D.R. \& Kennedy, K.N. 2002. An exploratory study of the Internet as an individual communication tool: examining buyer's perceptions. Industrial Marketing Management, 31:145-154.

Dempsey, W.A. 1978. Vendor selection and the buying process. Industrial Marketing Management, 7,256-267.

Diamond, J. \& Pintel, G. 2008. Retail buying. Prentice-Hall. 
De Boer, L., Labro, E. \& Morlacchi, O. 2001. A review of methods supporting supplier selection. European Journal of Purchasing and Supply Chain Management, 7:75-89.

Department of Economic Development. 2009. Creating an enabling environment for the growth of KZN craft: KwaZulu-Natal integrated craft hub business plan. Final, April.

Department of Arts, Culture, Science \& Technology. 1998. Cultural industries growth strategy (CIGS): the SA craft industry report. South Africa. November. Available: www.gov.za/documents/download.php?f=70487. Accessed 15 Nov. 2013.

Department of Labour. (2011). Labour market review: an investigation into the nature of employment relationships in the South African creative industry. Available: http://www.labour.gov.za/DOL/downloads/documents/research-documents/Creative\%20 Industries _DoL_Report.pdf. Accessed 15 Nov. 2013.

Department of Sports, Arts, Recreation \& Culture. (2007). Final draft Gauteng craft audit report, October 2007. Gauteng, South Africa.

Department of Trade \& Industry (DTI). (2005). Sector development strategy: craft. South Africa. Available: http://www.ccdi.org.za/research-and-publications/research/ Customised\% 20

Sector\%20Programme\%20for\%20Craft.pdf. Accessed 15 Nov. 2013.

DTI see Department of Trade \& Industry

Frost. A. \& Sullivan. (2005). Market feasibility study and business development plan for the handicrafts sector. Export Promotion Council for Handicrafts, New Delhi, India, August. Available: at http://epch.in/projects/Handicrafts\% 20Final\%20Report_August,\%202005.pdf. Accessed: 15 Nov. 2013.

Grobler, A.T. (2005). Product development for community-craft projects in Mpumalanga. An unpublished masters dissertation, University of Pretoria.

Hansen, K. 2001. Purchasing decision behaviour by Chinese supermarkets. International Review of Retail, Distribution and Consumer Research, 11(2):159-175.

Hay, D. (2008). The business of craft and crafting the business: strategies for success in the rural craft sector, 1-60. Retrieved from http://www.tcd.ufl.edu/Data/Sites/44/media/documents/tropilunch /2011/BusinesofCraft Handbook-lowresolution.PDF.

Hutt, M.D. \& Speh, T. W. (2007). Business marketing management: B2B. 9th ed. Australia: Thomson SouthWestern.

Jackson, D.W., Keith, J.E. \& Burdick, R.K. 1987. The relative importance of various promotional elements in different industrial purchase situations. Journal of Advertising, 16(4):25-33.

Kahraman, C., Cebeci, U. \& Ulukan, Z. 2003. Multi-criteria supplier selection using fuzzy AHP. Logistics Information Management, 16(6):382-394.

Kim, M. \& Boo, S. 2010. Understanding supplier selection criteria: meeting planner's approaches to selecting and maintaining suppliers. Journal of Travel \& Tourism Marketing, 27(5):507-518.

Kline, B. \& Wagner, J. 1994. Information sources and retail buyer decision making: the effect of product specific buying experience. Journal of Retailing, 70(1):75-88.

Lin, P.C \& Wu, L.S. 2011. How supermarket chains in Taiwan select suppliers of fresh fruit and vegetables via direct purchasing. The Service Industries Journal, 31(8):1237-1255.

Littrell, M.A., \& Miller, N.J. (2001). Marketing across cultures. Journal of Global Marketing, 15(1),67-86.

Luo, X., Wu, C., Rosenburg, D. \& Barnes, D. 2009. Supplier selection in agile supply chains: an information processing model and an illustration. Journal of Purchasing and Supply Management, 15:249-262.

Luutonen, M. 2009. Handmade marketing. Proceedings of the crafticulation and education conference. Research in Sloyd Education and Craft Science A, 14, 119-127. Available: https://helda.helsinki.fi/bitstream/handle/10224/4810/Kaukinen_verkko.pdf?sequence=2. Accessed: 15 Nov. 2013.

Makhitha, K.M. \& Bresler, N. (2011). The perceived marketing benefits of the 2010 FIFA World Cup for craft businesses. African Journal for Physical, Health Education, Recreation and Dance (Supplement), 232-252.

Malhotra, N.K. 2010. Marketing research: An applied orientation. $6^{\text {th }}$ Edition. New Jersey: Pearson Prentice Hall.

Obiri, M.N. 2002. Is market-led approach crucial to art and craft small and micro enterprises growth and sustainability in the Kwazulu-Natal Midlands? An unpublished master's dissertation, University of Natal.

Robinson, P.J., Faris, C.W. \& Wind, Y. 1967. Industrial buying and creative marketing. Boston: Allyn \& Bacon.

Rogerson, C.M. (2010). The enterprise of craft: constraints and policy challenges in South Africa. ActaAcademica, 42(3), 115-144. 
Sheth, J.N. 1981. A theory of merchandise buyer behaviour. Faculty working papers, College of Commerce and Business Administration, University of Illinois at Urbana-Champaign, August 29. Available: https://www.ideals.illinois.edu/bitstream/handle/2142/27923/theoryofmerchand706shet.pdf? sequence $=1$. Accessed: 15 Nov. 2013.

Sheth, J.N. 1973. A model of industrial buyer behaviour. Journal of Marketing, 37:50-56.

Sternquist, B. \& Chen, Z. 2006. Food retail buyer behaviour in the People's Republic of China: a grounded theory model. Qualitative Market Research: An International Journal, 9(3):243-265.

Torres, A.M. 2002 Marketing networks as a form of strategic alliance among craft enterprises. International Journal of Non-profit and Voluntary Sector Marketing, 7(3):229-243.

UNESCO. (1997). International Symposium on crafts and the international markets: Trade and customs codification. Final report. CLT/CONF/604/7. Available: http://unesdoc.unesco.org/images/0011/001114/111488eo.pdf. Accessed 15 Nov. 2013.

Urban-Econ Tourism. (2010). Feasibility study for Umbumbulu Arts and Crafts Trade Centre. Quotation 38DED/2008. Available: http://www.kznded.gov.za/ Portals/0/ 24.01.10\% 20 Umbumbulu\%20Craft \% 20Centre .pdf. Accessed 15 Nov. 2013.

USAID. 2006. Global market assessment for handicrafts. Available: http://pdf.usaid.gov/pdf docs/ PNADN210.pdf. Accessed 13 November 2013.

Webster, F.E. and Wind, Y. 1972. A general model for understanding organizational buying behaviour. The Journal of Marketing, 36(2):12-19.

Webster, F. E., \& Wind, Y. (1996). A general model for understanding organizational buying behaviour. Marketing Management, ABI/INFORMWinter/Spring, 4(4), 52-57.

Wesgro. 2000. Wesgro background on the craft industry in the Western Cape. August. South Africa. 